\title{
Activities of biotransformation enzymes and flubendazole metabolism in lambs (Ovis aries): effect of gender and flubendazole therapy
}

\author{
Hana Bártíková, Veronika Křrižová, Martina Štěpničková, Jiří Lamka, \\ Vladimír Kubíček, Lenka Skálová, Barbora Szotáková \\ Faculty of Pharmacy, Charles University, Heyrovského 1203, CZ-50005 Hradec Králové, Czech Republic
}

Correspondence: Barbora Szotáková, e-mail: Barbora.Szotakova@faf.cuni.cz

\begin{abstract}
:
The effect of flubendazole (FLU) therapy on in vitro FLU biotransformation and the activities of selected biotransformation enzymes were investigated in male and female lambs. Four experimental groups were used: control (untreated) ewes and rams and FLU-treated ewes and rams (orally, $15 \mathrm{mg} / \mathrm{kg}$ per day, for three consecutive days). Subcellular fractions were prepared from liver and intestinal mucosa $24 \mathrm{~h}$ after the final dosage was administered. Activities of cytochromes P450 (CYP), flavine monooxygenases (FMO), carbonyl reducing enzymes, UDP-glucuronosyl transferase (UGT) and glutathione S-transferase were tested. Significant gender differences were observed for FMO-mediated activity (2-fold higher in ram lambs) and UGT activity (up to 30\% higher in ewe lambs), but no gender differences were observed in FLU metabolism. FLU-treatment of lambs moderately changed the activities of some CYPs, FMO, and UGT in liver microsomes. In vitro FLU reduction was not altered in the liver, but was slightly higher in the small intestine of FLU pre-treated lambs. This correlated with the higher carbonyl reductase activities measured in the gut mucosa of these animals.
\end{abstract}

Key words:

flubendazole, ruminants, sheep, drug metabolism, anthelmintics

\section{Introduction}

Over the years, the benzimidazole anthelmintic flubendazole ([5-(4-fluorobenzoyl)-1H-benzimidazole-2-yl]-carbamic acid methyl ester, FLU) has provided broad spectrum efficacy against parasitic helminths, both adult and larval. FLU acts on parasites by the inhibition of tubulin-microtubule equilibrium without adverse reactions for the host [41]. FLU may be administered as a paste, in oral suspension, in pellets or supplemented with food as a premix formulation. FLU is more effective as a low level medication ad- ministered for several days ( 5 or 10 daily doses) than single dosing. Therefore, oral administration in feed is the most efficient method of administration in swineand poultry-breeding $[5,15,20]$.

When biotransformation of FLU was tested, similar metabolic pathways were found in several species. Reduction of the carbonyl group (reduced flubendazole, FLUR) and carbamate hydrolysis (hydrolyzed flubendazole, FLUH) were the major biotransformation reactions $[14,20,33]$.

Drug metabolism and activities of biotransformation enzymes play a pivotal role in determining drug 
permanence and efficacy in mammals. In this respect, the induction of xenobiotic metabolizing enzyme activities may accelerate drug elimination, leading to pharmacotherapy failure. Substrates of biotransformation enzymes may act as inducers as well. Therefore, an increased substrate level means a higher probability of enzyme induction. Moreover, in the case of anthelmintics, the possibility of developing parasite resistance can be increased because the effective level of drug is reduced. Due to the faster rate of biotransformation, some parasites are able to survive $[1,49]$.

The level of biotransformation enzymes is determined genetically and their expression is controlled hormonally, so drug metabolism may differ in males and females. Therefore, gender should be taken into account in drug biotransformation studies [e.g. 17]. The modulation of biotransformation enzymes by a drug acting either as an inducer or as an inhibitor may also change drug metabolism, leading to the aforementioned consequences. For this reason, the effects of drugs on biotransformation enzyme expression and activities should be carefully tested in all target species.

Until now, FLU has been prescribed only for swine and poultry, but the extension of its usage to small ruminants [31,33] (in oral suspension or with food as a premix) could be beneficial because of the broad spectrum of its anthelmintic activity. Additionally, FLU has a different biotransformation pattern in the host than other benzimidazoles due to the presence of carbonyl groups and absence of sulfur atoms in its molecule. Albendazole, fenbendazole and oxfendazole are the most widely used benzimidazoles in ruminant species. While sulfoxide metabolites are the main analytes detected in the bloodstream after the intraruminal administration of albendazole and fenbendazole $[28,29]$, the reduced FLU was generally the main molecule recovered in the systemic circulation of FLU-treated sheep [24, 33]. Higher concentrations of the lipophilic thioethers albendazole and fenbendazole were detected in Moniezia benedeni after ex vivo incubation, compared to their more polar sulfoxide metabolites [34]. A similar pattern of diffusion to the cestode parasite was observed for both FLU and reduced FLU, which probably indicates the similar lipid solubility of both albendazole and fenbendazole [33]. In experimental studies, FLU was used successfully in the therapeutic treatment of mouflon muelleriosis $[26,27]$.
The present project was designed to evaluate the effect of repeated administrations of FLU on xenobiotic metabolizing enzyme activities in male and female lambs. We used 4- to 5-month-old lambs, as anthelmintic therapy is recommended for animals of this age, when they are likely to have their first contact with the infective stages of parasites. The results were compared and the differences found were evaluated.

\section{Materials and Methods}

\section{Chemicals}

Albendazole [5-(propylthio)-2-benzimidazolecarbamic acid methyl ester, ABZ, used as internal standard] was purchased from Sigma-Aldrich (Czech Republic). Flubendazole ([5-(4-fluorobenzoyl)- $1 H$-benzimidazol2-y1]carbamic acid methyl ester, FLU) and its two main metabolites (reduced flubendazole [5-(4-fluorophenyl)hydroxymethyl-1H-benzimidazol-2-y1]-carbamic acid methyl ester, FLUR) and hydrolyzed flubendazole [(2-amino-1H-benz-imidazol-5-yl)-4-fluorophenyl] methanone, FLUH) were provided by Janssen Pharmaceutica (Belgium). All other chemicals (HPLC or analytical grade) were obtained from Sigma-Aldrich (Czech Republic).

\section{Animals and biological materials}

Ram and ewe lambs (Ovis aries, breed Merinolandschaf, 4- to 5-months-old) from a sheep farm (Skochovice, Czech Republic) were divided into 4 groups. Animals in the first group (4 ram lambs) and second group (4 ewe lambs) were experimentally treated with flubendazole (Flubenol 50\% premix, Janssen, Belgium); the drug was administered orally in suspension on three consecutive days $(15 \mathrm{mg} / \mathrm{kg}$ body weight per day). Control groups ( 3 ram and 3 ewe lambs) were administered a suspension without flubendazole. The same volume $(0.75 \mathrm{ml})$ of administered suspension per $\mathrm{kg}$ of body weight was used in all groups (oral suspension of the active substance in microcrystalline cellulose, Avicel RC-591, FMC, Belgium). All animals were treated individually, and none were subjected to other pharmacological treatments. Twenty four hours after the final dose was administered, the animals were culled (by stunning, then exsanguina- 
tion) in agreement with the Declaration of Helsinki and with Czech slaughtering guidelines for farm animals. A portion of the liver (lobus intermedialis) and $1.5 \mathrm{~m}$ of small intestine (measured from the beginning of the duodenum, i.e., duodenum and part of the jejunum) were removed immediately post mortem. The gut contents were washed out with $0.9 \%$ saline solution $\left(4^{\circ} \mathrm{C}\right)$. Both tissues were cut into small pieces and stored in liquid nitrogen during transportation to the laboratory.

\section{Preparation of subcellular fractions}

Frozen tissues were thawed at ambient temperature up to $15 \mathrm{~min}$. The intestinal pieces were cut open, washed and the mucosa scraped. Both mucosa and liver were homogenized using a Potter-Elvehjem homogenizer with a $0.1 \mathrm{M}$ sodium phosphate buffer, $\mathrm{pH}$ 7.4 , at the $\mathrm{w} / \mathrm{v}$ ratio of $1: 6$. The subcellular fractions were isolated by differential centrifugation of the tissue homogenates. A re-washing step (followed by the second ultracentrifugation) was included at the end of the microsomes preparation procedure. Pellets of microsomes were resuspended in a phosphate buffer containing $20 \%$ glycerol (v/v), and both microsomes and cytosol were stored at $-80^{\circ} \mathrm{C}$. Protein contents were determined using a bicinchoninic acid method according to the Sigma protocol.

\section{Enzyme assays}

The list of all substrates and their abbreviations is provided in Table 1. Each enzyme assay was performed in triplicate for each group, gender of animal and for each organ. Subcellular fractions from each group and gender were pooled, and each enzyme activity was determined three times, $n=3$. The rates of product formation were linear with time and within protein concentrations used in all enzymatic activities under study. The amount of organic solvents in the final reaction mixtures did not exceed $0.1 \%(\mathrm{v} / \mathrm{v})$.

The activities of several isoforms of CYPs were quantified. The levels of 7-ethoxyresorufin (EROD), 7methoxyresorufin (MROD), 7-pentoxyresorufin (PROD) $O$-dealkylases, and 7-benzyloxyresorufin $O$-dearylase (BROD) activity were determined at $37^{\circ} \mathrm{C}$ using fluorimetric determination of resorufin $[9,51]$. Substrate concentration was $5 \mu \mathrm{M}$ (dissolved in dimethyl sul-

Tab. 1. Enzyme activity assays - substrates and specificities. CYP - cytochrome P450; AKR - aldo-keto reductase; HSD - hydroxysteroid dehydrogenase; CBR - carbonyl reductase; UGT - UDP-glucuronosyl transferase; GST - glutathione S-transferase

\begin{tabular}{|c|c|c|c|}
\hline & Abbreviation used & Specific for human/rat & Reference \\
\hline 7-Ethoxyresorufin 0-dealkylase & EROD & CYP1A & {$[9,50]$} \\
\hline 7-Methoxyresorufin 0-dealkylase & MROD & CYP1A & {$[9,50]$} \\
\hline 7-Penthoxyresorufin 0-dealkylase & PROD & CYP2B & {$[9,50]$} \\
\hline 7-Benzyloxyresorufin 0-dearylase & BROD & CYP2B, CYP3A & {$[9,50]$} \\
\hline 7-Methoxy-4-trifluoromethyl-coumarin demethylase & MFCD & CYP2C & {$[13,40]$} \\
\hline 6-Chlorzoxazone hydroxylase & $\mathrm{CXOH}$ & CYP2E1, (CYP1A) & {$[39,44]$} \\
\hline Thiobenzamide oxidase & TBSO & FMO & {$[10]$} \\
\hline $\mathrm{D}, \mathrm{L}$-glyceraldehyde reductase & GALR & AKR1A & [23] \\
\hline Metyrapone reductase & METR (mic, cyt) & 11ß-HSD 1, AKR1C4, CBR & [30] \\
\hline 4-Pyridine-carboxaldehyde reductase & PCAR (mic, cyt) & $3 \alpha-H S D, A K R 1 A, A K R 1 C$ & [37] \\
\hline Daunorubicin reductase (pH 8.5) & DAUR8 & AKR1A & [36] \\
\hline Daunorubicin reductase (pH 6.0) & DAUR6 & AKR1C2, CBR & {$[16,36]$} \\
\hline Acenaphthenol dehydrogenase & ANDH & AKR1C1-4 & {$[8,38]$} \\
\hline Oracin dehydrogenase & ORDH (mic, cyt) & $11 \beta-H S D$ 1, AKR1C1-4, CBR & {$[48,52]$} \\
\hline p-Nitrophenol-UGT & UGT & UGT & [32] \\
\hline 1-Chloro-2,4-dinitrobenzene-GST & GST & GST & [19] \\
\hline
\end{tabular}


foxide, DMSO). Assays were performed using the Perkin-Elmer luminescence spectrophotometer LS $50 \mathrm{~B}$, with excitation and emission wavelengths of 530 $\mathrm{nm}$ and $585 \mathrm{~nm}$, respectively.

The 7-methoxy-4-trifluoromethylcoumarin demethylase (MFCD) activity was measured using fluorimetric determination of 4-trifluoromethylumbelliferone, the substrate concentration being $20 \mu \mathrm{M}$ (in DMSO). Excitation and emission wavelengths of $410 \mathrm{~nm}$ and $510 \mathrm{~nm}$, respectively, were used $[13,40]$.

A chlorzoxazone hydroxylase $(\mathrm{CXOH})$ assay was performed [39, 44]. The final concentration of substrate (dissolved in $60 \mathrm{mM} \mathrm{KOH}$ ) was $1 \mathrm{mM}$. The amount of 6-hydroxychlorzoxazone was determined by HPLC.

The activity of flavine monooxygenases toward thiobenzamide (TBSO) was assayed [10]. The final concentration of substrate (dissolved in acetonitrile) was $1 \mathrm{mM}$. The formation of S-oxide of thiobenzamide was measured spectrophotometrically at $370 \mathrm{~nm}$.

The activities of carbonyl reductases were tested using the following substrates: $1 \mathrm{mM}$ metyrapone (in redistilled water), $1 \mathrm{mM}$ D,L-glyceraldehyde (in DMSO), $1 \mathrm{mM}$ 4-pyridine-carboxaldehyde (in redistilled water) and $0.1 \mathrm{mM}$ daunorubicin (in redistilled water). Spectrophotometric determination $\left(340 \mathrm{~nm}, 25^{\circ} \mathrm{C}\right)$ of NADPH consumption served as the assessment of reductase activities [16, 23, 30, 36, 37].

Enzyme activities for $1 \mathrm{mM}$ acenaphthenol were determined $[8,38]$. The velocity of substrate dehydrogenation was determined spectrophotometrically by measuring the change in absorbance of a cofactor $\left(\mathrm{NADP}^{+}\right)$at $340 \mathrm{~nm}$.

Reductases of oracin were assayed as described previously $[48,52]$. Briefly, the concentration of oracin was $0.3 \mathrm{mM}$, with the amount of dihydrooracin being determined by HPLC using a $250 \mathrm{~mm} \times 4 \mathrm{~mm}$ BDH Hypersil C18 column. Dihydrooracin was detected with a fluorescence detector using an excitation wavelength of $340 \mathrm{~nm}$ and an emission wavelength of $418 \mathrm{~nm}$.

The microsomal UDP-glucuronosyl transferase (UGT) activity was assayed [32]. The final concentration of $p$-nitrophenol (in redistilled water) was $3.3 \mu \mathrm{M}$. Absorbance was measured using a BioRad microplate reader (detection wavelength $415 \mathrm{~nm}$ ).

Cytosolic glutathione-S-transferase (GST) activity was determined using $1 \mathrm{mM}$ 1-chloro-2,4-dinitrobenzene as a substrate (in ethanol). The absorbance increase at $340 \mathrm{~nm}$ was followed spectrophotometrically [19].

\section{Incubation of cytosolic fractions with FLU}

The reaction mixture (total volume of $0.3 \mathrm{ml}$ ) contained: $50 \mu \mathrm{l}$ of cytosol (0.4-0.6 $\mathrm{mg}$ of proteins), the substrate pre-dissolved in DMSO (concentration in the reaction mixture $1 \%)$, NADPH $(1 \mathrm{mM})$, and $0.1 \mathrm{M}$ Na-phosphate buffer, pH 7.4. The blank samples contained $50 \mu 1$ of $0.1 \mathrm{M}$ sodium phosphate buffer, $\mathrm{pH} 7.4$, instead of cytosol or $50 \mu 1$ of 10-minute-boiled cytosol. The biological blank samples contained $50 \mu 1$ of cytosol, DMSO instead of the substrate, NADPH, and $0.1 \mathrm{M}$ Na-phosphate buffer, $\mathrm{pH}$ 7.4. In the kinetic study, a concentration range $0.15-15.0 \mu \mathrm{M}$ of FLU was used. Higher concentrations of FLU were not available because FLU is poorly soluble in aqueous solutions. All incubations were carried out at $37^{\circ} \mathrm{C}$ for $30 \mathrm{~min}$ under aerobic conditions. The product formation was linear up to $60 \mathrm{~min}$. The reaction was terminated by cooling in ice and alkalization with $30 \mu \mathrm{l}$ ammonia solution; IS ( $3 \mu \mathrm{L}$ of $1 \mathrm{mM}$ albendazole) and $700 \mu 1$ of cooled ethyl acetate were added, shaken ( $3 \mathrm{~min}$., vortex) and centrifuged ( 5 min., $10,000 \times \mathrm{g}$ ). Supernatants were evaporated and dry residues stored at $-20^{\circ} \mathrm{C}$ until HPLC analyses.

\section{Analysis of FLU and its metabolites by HPLC}

Chromatographic analyses, performed with a Shimadzu liquid chromatograph, consisted of degasser GT-154, solvent delivery module LC-10ADvp, autoinjector SIL-10ADvp, column oven CTO-10Avp, UV/VIS photodiode array detector SPD-M10Avp, spectrofluorimetric detector RF-10AXL and system controller SCL-10Avp. The chromatograph was controlled by Shimadzu software CLASS-VP. A LiChroCART $250 \times 3 \mathrm{~mm}$ chromatographic column packed with LiChrospher $60 \mathrm{RP}$-select B, $5 \mu \mathrm{m}$ was used. The column was protected with a precolumn $4 \times 4 \mathrm{~mm}$ packed with the same stationary phase. The following chromatographic conditions were used: an isocratic mobile phase with a mixture of acetonitrile and $0.025 \mathrm{M}$ $\mathrm{KH}_{2} \mathrm{PO}_{4}$ buffer $\mathrm{pH}=3(3: 7, \mathrm{v} / \mathrm{v})$ delivered at a flow rate of $0.7 \mathrm{ml} / \mathrm{min}$. Using the photodiode array detector, chromatograms were recorded at $246 \mathrm{~nm}$ and $300 \mathrm{~nm}$ (scan 195-380 nm). With a spectrofluorimetric detector, excitation wavelength was allayed at $290 \mathrm{~nm}$ and emission wavelength at $320 \mathrm{~nm}$. FLUH, FLUR, albendazole (I.S.) and FLU were detected with the photodiode array detector. The spectrofluorimetric detector served for improving the sensitivity of FLUR detection (as FLUH and FLU are not fluo- 
Tab. 2. Specific activity of CYPS, FMO, carbonyl reducing enzymes, and UGT in the hepatic microsomes of control and FLU-treated lambs

\begin{tabular}{|c|c|c|c|c|}
\hline \multirow[b]{3}{*}{$\begin{array}{l}\text { Liver } \\
\text { microsomes }\end{array}$} & \multicolumn{4}{|c|}{ Specific activity (pmol/min.mg protein) } \\
\hline & \multicolumn{2}{|c|}{ Ram lambs ${ }^{\mathrm{a}}$} & \multicolumn{2}{|c|}{ Ewe lambs ${ }^{\mathrm{a}}$} \\
\hline & Control & $\begin{array}{l}\text { FLU } \\
\text { treated }\end{array}$ & Control & $\begin{array}{l}\text { FLU } \\
\text { treated }\end{array}$ \\
\hline EROD & $\begin{array}{l}70.8 \\
\pm 3.9\end{array}$ & $\begin{array}{l}126.9 \\
\pm 7.9^{\star}\end{array}$ & $\begin{array}{l}85.1 \\
\pm 3.5^{\#}\end{array}$ & $\begin{array}{l}83.6 \\
\pm 3.2\end{array}$ \\
\hline MROD & $\begin{array}{l}79.5 \\
\pm 1.4\end{array}$ & $\begin{array}{l}121.5 \\
\pm 4.4^{*}\end{array}$ & $\begin{array}{l}99.1 \\
\pm 4.3^{\#}\end{array}$ & $\begin{array}{l}69.0 \\
\pm 7.5^{*}\end{array}$ \\
\hline BROD & $\begin{array}{l}19.6 \\
\pm 3.1\end{array}$ & $\begin{array}{l}25.5 \\
\pm 2.9\end{array}$ & $\begin{array}{l}22.1 \\
\pm 2.3\end{array}$ & $\begin{array}{l}19.5 \\
\pm 2.2\end{array}$ \\
\hline PROD & $\begin{array}{l}3.41 \\
\pm 1.12\end{array}$ & $\begin{array}{l}2.80 \\
\pm 1.14\end{array}$ & $\begin{array}{c}3.35 \\
\pm 1.47\end{array}$ & $\begin{array}{l}1.78 \\
\pm 0.92\end{array}$ \\
\hline MFCD & $\begin{array}{l}609 \\
\pm 50\end{array}$ & $\begin{array}{l}927 \\
\pm 65^{\star}\end{array}$ & $\begin{array}{l}610 \\
\pm 52\end{array}$ & $\begin{array}{l}875 \\
\pm 28^{\star}\end{array}$ \\
\hline $\mathrm{CXOH}$ & $\begin{array}{l}403 \\
\pm 73\end{array}$ & $\begin{array}{c}249 \\
\pm 66^{\star}\end{array}$ & $\begin{array}{l}403 \\
\pm 78\end{array}$ & $\begin{array}{c}167 \\
\pm 86^{\star}\end{array}$ \\
\hline TBSO & $\begin{array}{r}3032 \\
\pm 96\end{array}$ & $\begin{array}{l}3478 \\
\pm 89^{\star}\end{array}$ & $\begin{array}{l}1783 \\
\pm 162^{\#}\end{array}$ & $\begin{array}{l}1467 \\
\pm 274\end{array}$ \\
\hline METRmic & $\begin{array}{l}1146 \\
\pm 513\end{array}$ & $\begin{array}{l}1182 \\
\pm 528\end{array}$ & $\begin{array}{l}550 \\
\pm 341\end{array}$ & $\begin{array}{l}317 \\
\pm 204\end{array}$ \\
\hline PCARmic & $\begin{array}{l}14989 \\
\pm 1195\end{array}$ & $\begin{array}{l}14656 \\
\pm 1130\end{array}$ & $\begin{array}{l}17480 \\
\pm 1288\end{array}$ & $\begin{array}{l}12910 \\
\pm 1142\end{array}$ \\
\hline ORDHmic & $\begin{array}{l}31.9 \\
\pm 2.5\end{array}$ & $\begin{array}{l}58.5 \\
\pm 1.8^{\star}\end{array}$ & $\begin{array}{l}54.6 \\
\pm 5.4^{\#}\end{array}$ & $\begin{array}{l}78.8 \\
\pm 2.5^{*}\end{array}$ \\
\hline UGT & $\begin{array}{l}7007 \\
\pm 187\end{array}$ & $\begin{array}{l}9132 \\
\pm 556^{\star}\end{array}$ & $\begin{array}{l}9144 \\
\pm 241^{\#}\end{array}$ & $\begin{array}{l}9142 \\
\pm 329\end{array}$ \\
\hline
\end{tabular}

* Significantly different comparing control and FLU-treated animals (ANOVA, $p<0.05$ ). \# Significantly different comparing male and female lambs (ANOVA, $p<0.05$ ). a Subcellular fractions from each group and gender were pooled and each enzyme activity was determined three times, $n=3$

rescent). The limit of quantitation for FLU was $90 \mathrm{nM}$, for FLUH $80 \mathrm{nM}$, and for FLUR $0.2 \mathrm{nM}$ [25, 35]. Fifty $\mu 1$ of each sample were injected. The duration of the complete analysis was $22 \mathrm{~min}$.

\section{Data and statistical analysis}

The reported data are expressed as the mean $\pm \mathrm{SD}$. Data analysis was performed using Single Factor ANOVA (Microsoft Office Excel 2007). A value of $\mathrm{p}<0.05$ was considered significant.
Tab. 3. Specific activity of carbonyl reducing enzymes and UGT in small intestinal microsomes of control and FLU-treated lambs

\begin{tabular}{ccccc}
\hline & \multicolumn{3}{c}{ Specific activity (pmol/min.mg protein) } \\
\cline { 2 - 5 } & \multicolumn{2}{c}{ Ram lambs $^{\mathrm{a}}$} & \multicolumn{2}{c}{ Ewe lambs $^{\mathrm{a}}$} \\
\hline $\begin{array}{c}\text { Intestinal } \\
\text { microsomes }\end{array}$ & Control & FLU & Control & $\begin{array}{c}\text { FLU } \\
\text { treated }\end{array}$ \\
treated & & 1096 \\
PCARmic & 1032 & 869 & 1071 & 1096 \\
& \pm 551 & \pm 234 & \pm 273 & \pm 138 \\
ORDHmic & 24.2 & 21.7 & 17.6 & 36.4 \\
& \pm 1.8 & \pm 0.9 & $\pm 0.9^{\#}$ & $\pm 0.6^{*}$ \\
UGT & 1148 & 1311 & 1392 & 1727 \\
& \pm 899 & \pm 895 & \pm 886 & \pm 593 \\
\hline
\end{tabular}

* Significantly different comparing control and FLU-treated animals (ANOVA, $p<0.05$ ). \# Significantly different comparing male and female lambs (ANOVA, $p<0.05$ ). a Subcellular fractions from each group and gender were pooled and each enzyme activity was determined three times, $n=3$

\section{Results}

\section{Effect of FLU treatment on activities of the microsomal biotransformation enzymes}

Activities of CYPs (EROD, MROD, BROD, PROD, MFCD, CXOH), FMO (TBSO), carbonyl-reducing enzymes (METRmic, PCARmic, ORDHmic), and UGT (for enzymes and their abbreviations see Tab. 1) were measured in hepatic microsomes (Tab. 2) and in microsomes prepared from intestinal mucosa (Tab. 3). In small intestinal microsomes, all activities were measured but only PCARmic, ORDHmic and UGT activities were detected.

The results show that activities of hepatic enzymes were significantly higher in ram lambs after FLU treatment: EROD (by 79\%), MROD (by 50\%), MFCD (by $52 \%$ ), TBSO (by $15 \%$ ), ORDHmic (by $83 \%$ ), and UGT (by 30\%) (p < 0.05, ANOVA). CXOH activity was significantly reduced by $38 \%$.

In ewe lambs, only activities of MFCD (by 43\%), and ORDHmic (by 44\%) $(\mathrm{p}<0.05$, ANOVA) in the liver were increased in FLU treated animals. MROD and $\mathrm{CXOH}$ activities were significantly reduced (by $30 \%$ and 58\%, respectively) after FLU treatment. 
Tab. 4. Specific activity of carbonyl reducing enzymes and GST in the hepatic cytosol of control and FLU-treated sheep

\begin{tabular}{|c|c|c|c|c|}
\hline \multirow[b]{3}{*}{$\begin{array}{l}\text { Liver } \\
\text { cytosol }\end{array}$} & \multicolumn{4}{|c|}{ Specific activity (nmol/min.mg protein) } \\
\hline & \multirow{2}{*}{$\frac{\text { Ram lambs }}{\text { Control }}$} & \multicolumn{3}{|c|}{ Ewe lambs ${ }^{a}$} \\
\hline & & $\begin{array}{l}\text { FLU } \\
\text { treated }\end{array}$ & Control & $\begin{array}{l}\text { FLU } \\
\text { treated }\end{array}$ \\
\hline $\mathrm{ANDH}$ & $\begin{array}{l}20.6 \\
\pm 1.2\end{array}$ & $\begin{array}{l}20.3 \\
\pm 1.6\end{array}$ & $\begin{array}{l}20.5 \\
\pm 1.0\end{array}$ & $\begin{array}{l}26.7 \\
\pm 1.4^{\star}\end{array}$ \\
\hline METR & $\begin{array}{l}0.66 \\
\pm 0.10\end{array}$ & $\begin{array}{l}0.99 \\
\pm 0.18^{\star}\end{array}$ & $\begin{array}{l}0.6 \\
\pm 0.19\end{array}$ & $\begin{array}{l}1.46 \\
\pm 0.54^{*}\end{array}$ \\
\hline DAUR6 & $\begin{array}{l}1.17 \\
\pm 0.12\end{array}$ & $\begin{array}{l}0.50 \\
\pm 0.05^{\star}\end{array}$ & $\begin{array}{l}1.00 \\
\pm 0.11\end{array}$ & $\begin{array}{l}0.80 \\
\pm 0.15\end{array}$ \\
\hline DAUR8 & $\begin{array}{l}1.30 \\
\pm 0.18\end{array}$ & $\begin{array}{l}1.03 \\
\pm 0.11\end{array}$ & $\begin{array}{l}0.75 \\
\pm 0.09^{\#}\end{array}$ & $\begin{array}{l}0.92 \\
\pm 0.12\end{array}$ \\
\hline GALR & $\begin{array}{l}8.38 \\
\pm 0.44\end{array}$ & $\begin{array}{l}6.04 \\
\pm 0.52^{*}\end{array}$ & $\begin{array}{l}5.79 \\
\pm 0.27^{\#}\end{array}$ & $\begin{array}{l}7.38 \\
\pm 0.60^{*}\end{array}$ \\
\hline PCAR & $\begin{array}{l}59.0 \\
\pm 16.9\end{array}$ & $\begin{array}{l}122.9 \\
\pm 6.8^{*}\end{array}$ & $\begin{array}{l}87.3 \\
\pm 4.8^{\#}\end{array}$ & $\begin{array}{l}125.4 \\
\pm 6.2^{*}\end{array}$ \\
\hline $\mathrm{ORDH}$ & $\begin{array}{l}1.19 \\
\pm 0.07\end{array}$ & $\begin{array}{l}1.42 \\
\pm 0.04^{*}\end{array}$ & $\begin{array}{l}1.34 \\
\pm 0.04^{\#}\end{array}$ & $\begin{array}{l}1.58 \\
\pm 0.01^{*}\end{array}$ \\
\hline GST & $\begin{array}{l}520 \\
\pm 81\end{array}$ & $\begin{array}{l}432 \\
\pm 39\end{array}$ & $\begin{array}{l}345 \\
\pm 107^{\#}\end{array}$ & $\begin{array}{l}590 \\
\pm 44^{*}\end{array}$ \\
\hline
\end{tabular}

* Significantly different comparing control and FLU-treated animals (ANOVA, $p<0.05$ ). " Significantly different comparing male and female lambs (ANOVA, $p<0.05$ ). a Subcellular fractions from each group and gender were pooled and each enzyme activity was determined three times, $n=3$

Neither CYPs nor FMO activity was detected in intestinal microsomal fraction. Intestinal PCARmic, ORDHmic and UGT were not affected by FLU treatment in rams; ORDHmic activity was significantly higher (by 107\%) in FLU-treated ewe lambs.

\section{Effect of FLU treatment on the activities of cytosolic biotransformation enzymes}

Activities of GALR, METR, PCAR, DAUR8, DAUR6, ANDH, ORDH, and GST (for enzymes and their abbreviations see Tab. 1) were measured in hepatic (Tab. 4) and intestinal cytosol (Tab. 5).

The results (Tab. 4) show that activities of reductases/dehydrogenases significantly differ, depending on the substrate used. Significant differences $(\mathrm{p}<0.05$, ANOVA) in activities of METR, DAUR, GALR, PCAR and ORDH between control and FLU-treated ram lambs were observed. Compared with the controls, FLU treatment caused an increase in METR and
Tab. 5. Specific activity of carbonyl reducing enzymes and GST in the small intestinal cytosol of control and FLU-treated sheep

\begin{tabular}{lllll}
\hline & \multicolumn{3}{c}{ Specific activity (nmol/min.mg protein) } \\
\cline { 2 - 5 } & \multicolumn{2}{c}{ Ram lambs $^{\mathrm{a}}$} & \multicolumn{2}{c}{ Ewe lambs $^{\mathrm{a}}$} \\
\cline { 2 - 5 } $\begin{array}{c}\text { Intestinal } \\
\text { cytosol }\end{array}$ & Control & $\begin{array}{c}\text { FLU } \\
\text { treated }\end{array}$ & Control & \multicolumn{1}{c}{ FLU } \\
treated
\end{tabular}

n.d. - not detected. * Significantly different comparing control and FLU-treated animals (ANOVA, $p<0.05$ ). ${ }^{a}$ Subcellular fractions from each group and gender were pooled and each enzyme activity was determined three times, $n=3$

ORDH activities (by $30 \%$ and $13 \%$, respectively) and an almost twofold increase of PCAR activity in liver cytosol of ram lambs. On the other hand, FLU caused a significant decrease in DAUR6 (by 57\%) and GALR (by 28\%) activities in ram lambs. ANDH, DAUR8 and GST activity were not changed in males.

In ewe lambs, significantly increased activities of ANDH (by 30\%), METR (by 143\%), GALR (by $27 \%$ ), PCAR (by 44\%), ORDH (by 18\%), and GST (by $71 \%$ ) after FLU treatment were measured in liver cytosol. Only DAUR6 and DAUR8 activities were not changed in females.

In the small intestinal cytosol of ram lambs, several enzyme activities were significantly higher after FLU treatment: METR (by 79\%), DAUR8 (by 125\%), and ORDH (by 13\%). GALR activity was detected only after FLU treatment and PCAR was the only enzyme that exhibited decreased activity (Tab. 5). Enzyme activities were affected in the intestinal cytosol of ewes as well. ANDH, METR, DAUR8, GALR, and ORDH activities were increased; PCAR and GST activities were decreased. 


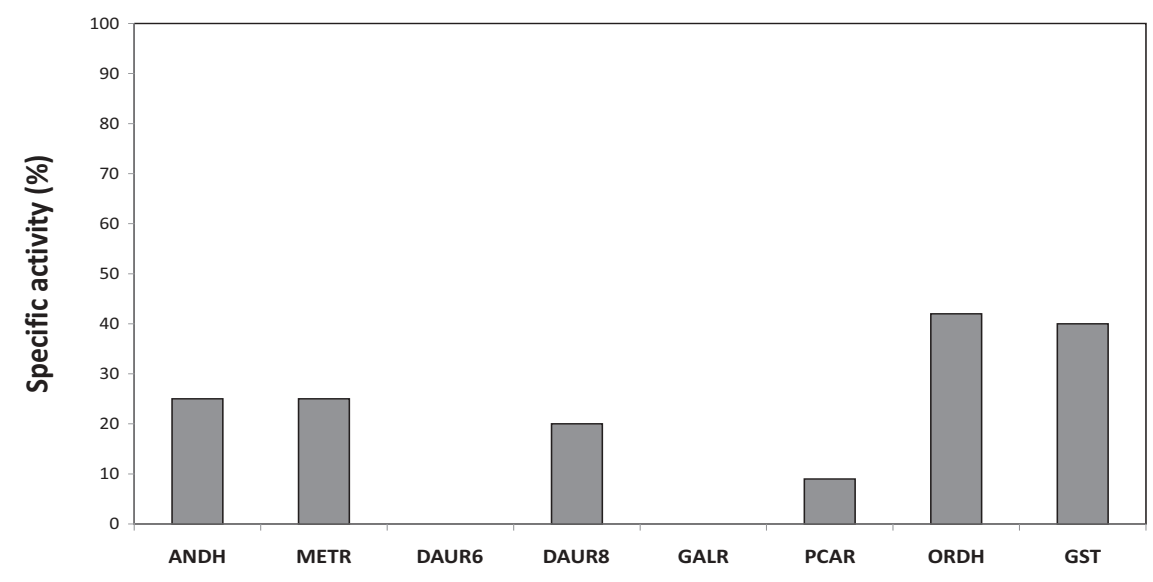

Fig. 1. Specific activity in intestinal cytosol expressed as \% of liver cytosol activity (activity in liver cytosol = $100 \%$ )

Specific activities of carbonyl reducing enzymes and GST were higher in the liver than in small intestine (by 60-100\%, Fig. 1).

\section{Sex differences in biotransformation enzyme activities}

Comparing control ram and ewe lambs, hepatic enzyme activities of EROD, MROD, ORDHmic and UGT were significantly higher in ewes. Conversely, TBSO activity in ewe lambs reached only about half the activity of ram lambs. GALR, DAUR8 and GST activities were lower in the liver cytosol of ewes, but $\mathrm{ORDH}$ and PCAR activities were higher compared to rams ( $p<0.05$, one-way ANOVA) (Tab. 2 and 3 ).

Activities of intestinal microsomal enzymes in control ram and ewe lambs were similar in both genders, with only ORDHmic being significantly higher in rams. No differences in cytosolic enzyme activities in the small intestine were observed between male and female lambs (see Tab. 4 and 5).

\section{In vitro reduction of FLU in the cytosol of control and FLU-treated sheep}

FLU $(0-15 \mu \mathrm{M})$ was incubated with liver or intestinal cytosol of control and FLU-treated male or female sheep. No measurable FLUR production occurred in the blank incubation either without cytosol or with boiled cytosol. No traces of FLU or FLUR were detected in biological blank samples (incubation of cytosol without FLU). From the raw data, mean values and standard deviations of reaction velocity were calculated (GraphPad Prism 5.00 software).

In the liver, velocity of FLUR formation by carbonyl reducing enzymes was measured at a concen- tration of FLU $0-15 \mu \mathrm{M}$. In this concentration range, velocity increased linearly. Because of the poor solubility of FLU in aqueous solutions, higher concentrations of substrate could not be used. FLU treatment did not affect the velocity in ram or ewe lambs (Fig. 2). Similarly, no significant differences were detected in the velocity in control ram and ewe lambs.

Results obtained in the intestinal cytosol are expressed as plots of velocity of FLUR formation $v s$. substrate concentration (Fig. 3 and 4). The apparent kinetic parameters maximal velocity $\left(\mathrm{V}_{\max }{ }^{\prime}\right)$, Michaelis constant $\left(\mathrm{K}_{\mathrm{m}}{ }^{\prime}\right)$, and intrinsic clearance $\left(\mathrm{Cl}_{\text {int }}\right)$ were calculated using the GraphPad Prism 5.00 software (Tab. 6).

Both in ram lambs and ewe lambs, FLU treatment significantly $(\mathrm{p}<0.05)$ increased the velocity of FLUR formation in small intestine. Values of $\mathrm{V}_{\max }$, were significantly higher in FLU-treated animals, $65 \%$ in rams and $50 \%$ in ewes. $\mathrm{K}_{\mathrm{m}}$ ' values were not affected. Values of intrinsic clearance were not changed in FLU-treated animals compared to controls.

Tab. 6. Apparent kinetic parameters of reduced flubendazole formation in cytosol from intestinal mucosa

\begin{tabular}{lccc}
\hline & $\begin{array}{c}\mathrm{V}_{\text {max }}{ }^{\prime} \\
(\mathrm{pmol} / \mathrm{min} . \mathrm{mg})\end{array}$ & $\begin{array}{c}\mathrm{K}_{\mathrm{m}}{ }^{\prime} \\
(\mu \mathrm{M})\end{array}$ & $\begin{array}{c}\mathrm{Cl}_{\text {int }} \\
(\mathrm{ml} / \mathrm{min} . \mathrm{mg})\end{array}$ \\
\hline Ram lambs, control $^{\mathrm{a}}$ & $10.38 \pm 0.62$ & $4.10 \pm 0.66$ & $2.53 \pm 0.94$ \\
Ram lambs, FLU-treated $^{\mathrm{a}}$ & $17.15 \pm 0.70^{*}$ & $4.10 \pm 0.45$ & $4.18 \pm 1.56$ \\
Ewe lambs, control $^{\mathrm{a}}$ & $9.49 \pm 0.54$ & $3.67 \pm 0.46$ & $2.59 \pm 1.17$ \\
Ewe lambs, FLU-treated $^{\mathrm{a}}$ & $14.24 \pm 0.85^{\star}$ & $3.96 \pm 0.64$ & $3.60 \pm 1.33$ \\
\hline
\end{tabular}

* Significantly different comparing control and FLU-treated animals (ANOVA, p < 0.05). ' Subcellular fractions from each group and gender were pooled and each enzyme activity was determined four times, $n=4$ 

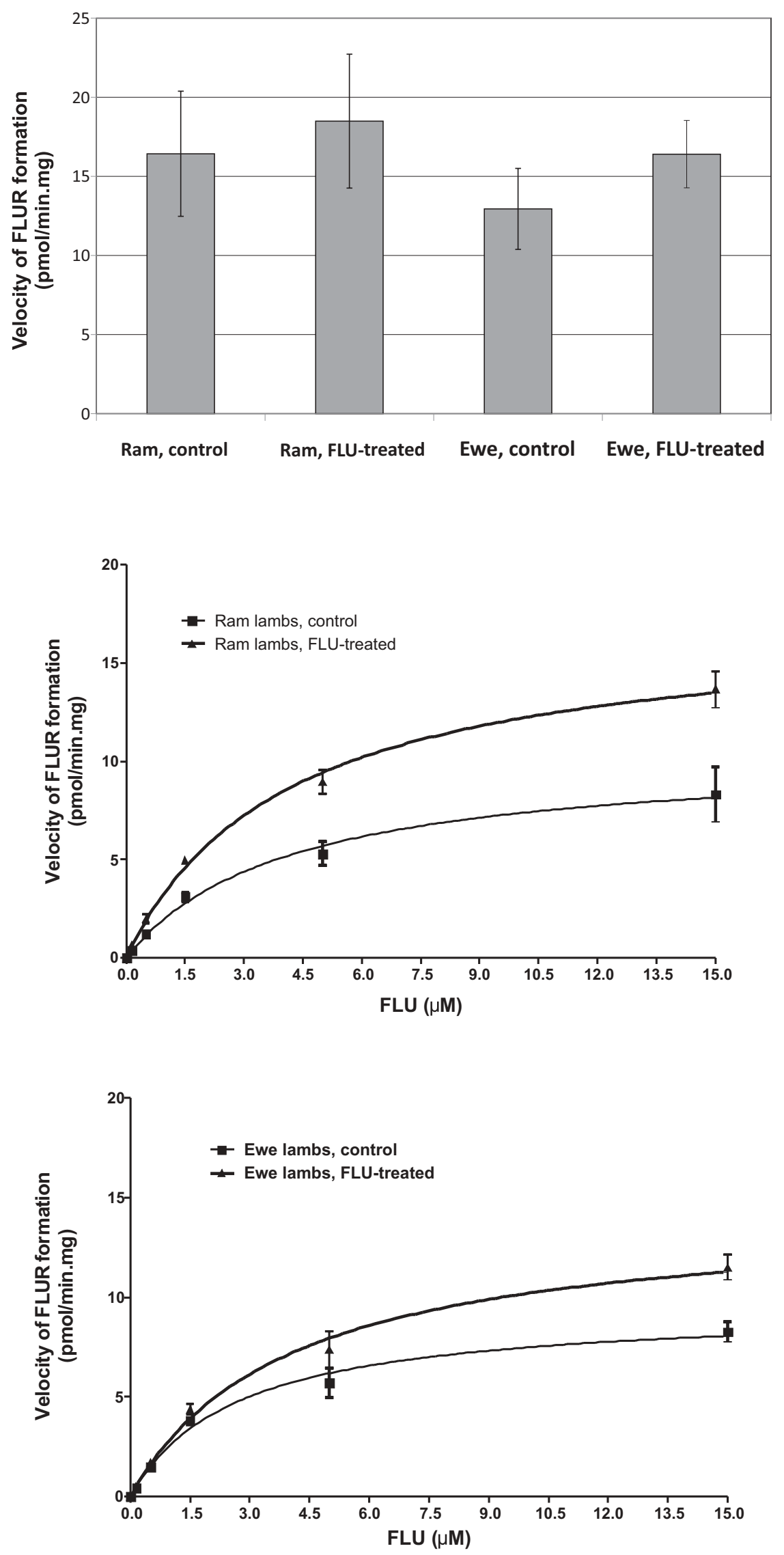

Fig. 2. Velocity of reduced flubendazole (FLUR) formation in hepatic cytosol of control and FLU-treated ram and ewe lambs (incubation with $15 \mu \mathrm{M}$ FLU). Cytosolic fractions from each group and gender were pooled and each enzyme activity was determined four times, $n=4$

Fig. 3. Velocity of reduced flubendazole (FLUR) formation in intestinal cytosol of control and FLU-treated ram lambs. Cytosolic fractions from each group and gender were pooled and each enzyme activity was determined four times, $n=4$

Fig. 4. Velocity of reduced flubendazole (FLUR) formation in intestinal cytosol of control and FLU-treated ewe lambs. Cytosolic fractions from each group and gender were pooled and each enzyme activity was determined four times, $n=4$ 


\section{Discussion}

The study presented here focused on the in vitro FLU biotransformation and activities of several biotransformation enzymes in control and in FLU-treated ram and ewe lambs (4- to 5- months old). Therapy with benzimidazole anthelmintics is frequently used with animals of this age, because at this time their first contact with infective stages of parasites on farms can occur. Moreover, parasitoses in young animals can be especially dangerous [22].

We tested the effect of FLU and gender not only on hepatic enzymes but also on enzymes of intestinal mucosa, as metabolism in the gut wall can decrease the bioavailability and pharmacological effects of a wide variety of orally administered drugs [21].

FLU can affect biotransformation enzymes in a different manner. The inhibition of some CYPs by FLU has been described in rats [50], but no effect of FLU on CYP1A and CYP3A in porcine and pheasant hepatocytes [3] has been observed. FLU treatment of pigs enhances porcine intestinal UGT activity, but no effect on other biotransformation enzymes is observed [42]. Carbonyl-reducing enzyme activities are increased by FLU in pheasants [43], whereas FLU does not affect these enzymes in pigs [47].

The enzyme activities tested and specificities of these enzymes generally accepted in human or rat subcellular fractions are completed in Table 1. MROD and EROD are used as marker activities for CYP1A not only in human and rat, but also in several other species $[6,9,51]$. The CYP substrates used in this study were also successfully used in our previous study, where in vitro activities of biotransformation enzymes in pig, cattle, goat and sheep were measured [46]. In the present study, activities of CYPs, FMO, carbonyl-reducing enzymes, and UGT were measured in microsomes of control and FLU-treated ram and ewe lambs. The results proved a significant increase in CYP1A (MROD, EROD) and CYP2C (MFCD) hepatic activities in male sheep treated with FLU. A decrease in CYP2E1 activity was observed both in ram and ewe lambs, while in ewes MROD activity was also inhibited.

Flavin-containing monooxygenases are important in detoxification but are generally considered not to be inducible by xenobiotics. Recent microarray studies [11] revealed induction of FMO2 and FMO3
mRNAs by 2,3,7,8-tetrachlorodibenzo- $p$-dioxin in liver of mice with wild-type aryl hydrocarbon receptor (Ahr) but not in Ahr-null mice. Higher FMO activity in FLU-treated ram lambs may be caused by a similar mechanism. Significant gender differences were observed in FMO activity. TBSO activity in ewe lambs reached only about half the activity in ram lambs. Gender differences in the activity of these enzymes were documented earlier in mature mice and rats. Hepatic FMO1 exhibits gender-dependent expression in both species; it is expressed only in the male in rats and in the female in mice. FMO3 in mice is gender-specific to the female, but genderindependent in rats. FMO5 is gender-independent for both mice and rats [12].

The activities of microsomal carbonyl reductases (ORDHmic, METRmic) both in males and in females were significantly higher after FLU treatment. Treatment of ram lambs with FLU led to significant increases in hepatic UGT, but not in intestinal UGT activity; no differences were observed in ewe lambs. Comparing control ram and ewe lambs, hepatic UGT activities were significantly higher in ewes. Genderspecific UGT gene expression is observed in liver and kidney of mice [7].

Cytosolic ketone reductases were included in our study because a reduction of the carbonyl group gives rise to the main FLU metabolite (FLUR) in the first phase of biotransformation [14, 18, 31]. Moreover, aldo-keto reductases together with short-chain dehydrogenases/reductases regulate a wide range of physiological processes including reproduction, development and homeostasis. Induction or inhibition of these enzymes may significantly affect the endogenous metabolism [4]. Compared with the controls, FLU treatment caused both an increase and a decrease in the activities of carbonyl reducing enzymes, depending on the substrate used. Gender differences were also observed, ram lambs showed higher DAUR and GALR as well as lower PCAR and ORDH activities.

Subcellular fractions obtained from sheep liver and duodenal mucosa metabolized FLU into a reduced FLU metabolite (FLUR). An NADPH-dependent carbonyl reductase (CBR) is proposed as the main enzymatic system involved in the keto-reduction of FLU in sheep [31]. Substrates of carbonyl reducing enzymes may act as their inducers as well $[2,45]$, and is likely one of the mechanisms involved in CBR induction. To evaluate the influence of repeated FLU administration on the metabolism of FLU itself, in vitro 
metabolism of FLU was studied and compared in control and FLU-treated animals. The velocity of FLU hepatic reduction increased linearly with increasing concentrations of substrate $(0-15 \mu \mathrm{M}$ FLU). Kinetic parameters could not be determined for this reason. The highest concentration of FLU that could be dissolved in the incubation medium was $15 \mu \mathrm{M}$ and higher concentrations would be necessary for the estimation of kinetic parameters. In intestinal mucosa, the maximal velocity $\left(\mathrm{V}_{\max }\right.$ ') of FLUR formation was significantly higher in cytosol from FLU-treated animals. These findings are in agreement with the results of the testing of FLU effect on CBR activity in ovine intestines, where significantly higher activities of METR, DAUR6 and ORDH (these substrates are markers for the activities of the CBR enzymatic system) after FLUtreatment were observed. Similar results were obtained in a study with pheasants [47], where a significant increase in the velocity of FLUR formation was observed in hepatic (by 45\%) and intestinal (by 20\%) cytosol taken from FLU-treated birds.

In conclusion, our results showed that the repeated administration of FLU to lambs changed some biotransformation enzyme activities significantly. FLU reduction to FLUR was significantly greater in intestinal cytosol, but not altered in hepatic cytosol. Significant gender differences were observed in FMO and UGT activity, but no gender differences were observed in FLU metabolism. Changes found in enzyme activities and in FLU biotransformation were statistically significant, but too low $(10-40 \%)$ to take into consideration for sheep anthelmintic therapy with FLU. Furthermore, the same therapy can be used in the treatment of ewe and ram lambs.

\section{Acknowledgment:}

Financial support of this project was provided by Czech Science Foundation, grant No. 524/06/1345.

\section{References:}

1. Aix L, Rey-Grobellet X, Larrieu G, Lesca P, Galtier P: Thiabendazole is an inducer of cytochrome P4501A1 in cultured rabbit hepatocytes. Biochem Biophys Res Commun, 1994, 202, 1483-1489.

2. Ax W, Soldan M, Koch L, Maser E: Development of daunorubicin resistance in tumour cells by induction of carbonyl reduction. Biochem Pharmacol, 2000, 59, 293-300.
3. Baliharova V, Velik J, Savlik M, Szotakova B, Lamka J, Tahotna L, Skalova L: The effects of fenbendazole, flubendazole and mebendazole on activities of hepatic cytochromes P450 in pig. J Vet Pharmacol Ther, 2004, 27, 1-6.

4. Bauman DR, Steckelbroeck S, Penning TM: The roles of aldo-keto reductases in steroid hormone action. Drug News Perspect, 2004, 17, 563-578.

5. Bishop Y: The Veterinary Formulary, 5th edn., London, Pharmaceutical Press, 2001.

6. Bogaards JJP, Bertrand M, Jackson P, Oudshoorn MJ, Weawer RJ, van Bladeren PJ, Walther B: Determining the best animal model for human cytochrome P450 activities: a comparison of mouse, rat, rabbit, dog, micropig, monkey and man. Xenobiotica, 2000, 30, 1131-1152.

7. Buckley DB, Klaassen CD: Tissue- and gender-specific mRNA expression of UDP-glucuronosyl transferases (UGTs) in mice. Drug Metab Dispos, 2007, 35, 121-127.

8. Burczynski ME, Lin HK, Penning TM: Isoform-specific induction of a human aldo-keto reductase by polycyclic aromatic hydrocarbons (PAHs), electrophiles, and oxidative stress: implications for the alternative pathway of PAH activation catalyzed by human dihydrodiol dehydrogenase. Cancer Res, 1999, 59, 607-614.

9. Burke MD, Thompson S, Weaver RJ, Wolf CR, Mayer RT: Cytochrome P450 specificities of alkoxyresorufin O-dealkylation in human and rat liver. Biochem Pharmacol, 1994, 48, 923-936.

10. Cashman JR, Hanzlik RP: Microsomal oxidation of thiobenzamide. A photometric assay for the flavincontaining monooxygenase. Biochem Biophys Res Commun, 1981, 98, 147-153.

11. Celius T, Roblin S, Harper PA, Matthews J, Boutros PC, Pohjanvirta R, Okey AB: Aryl hydrocarbon receptordependent induction of flavin-containing monooxygenase mRNAs in mouse liver. Drug Metab Dispos, 2008, 36, 2499-2505.

12. Cherrington NJ, Cao Y, Cherrington JW, Rose RL, Hodgson E: Physiological factors affecting protein expression of flavin-containing monooxygenases 1, 3 and 5. Xenobiotica, 1998, 28, 673-682.

13. Crespi CL, Stresser DM: Flourimetric screening for metabolism-based drug-drug interactions. J Pharm Toxicol Methods, 2000, 44, 325-331.

14. Danaher M, De Ruyck H, Crooks SRH, Dowling G, O'Keeffe MJ: Review of methodology for the determination of benzimidazole residues in biological matrices. J Chromatogr B, 2007, 845, 1-37.

15. De Ruyck H, Daeseleire E, Grijspeerdt K, De Ridder H, Van Renterghem R, Huyghebaert G: Distribution and depletion of flubendazole and its metabolites in edible tissues of guinea fowl. Br Poultry Sci, 2004, 45, 540-549.

16. Felsted RL, Bachur NR: Mammalian carbonyl reductases. Drug Metab Rev, 1980, 11, 1-60.

17. Gibson GG, Skett P: Introduction to drug metabolism, 3rd ed., Nelson Thornes Publishers, Cheltenham, 2001.

18. Gottschall DW, Theodorides VJ, Wang R. The metabolism of benzimidazole anthelmintics. Parasitol Today, 1990, 6, 115-124.

19. Habig WH, Jakoby WB: Glutathione S-transferases (rat and human). Methods Enzymol, 1981, 77, 218-231. 
20. http://www.emea.europa.eu/pdfs/vet/mrls/3312806en.pdf [consulted 20 January 2009].

21. Ilett KF, Tee LBG, Reeves PT, Minchin RF: Mebolism of drugs and other xenobiotics in the gut lumen and wall. Pharmacol Ther, 1990, 46, 67-93.

22. Kassai T: Veterinary Helminthology. Oxford, Butterworth Heinemann, 1999.

23. Kawamura M, Eisenhofer G, Kopin IJ, Kador PF, Lee YS, Tsai JY, Fujisawa $\mathrm{S}$ et al.: Aldose reductase, a key enzyme in the oxidative deamination of norepinephrine in rats. Biochem Pharmacol, 1999, 58, 517-524.

24. Krizova V, Nobilis M, Pruskova L, Chladek J, Szotakova B, Cvilink V, Skalova L, Lamka J: Pharmacokinetics of flubendazole and its metabolites in lambs and adult sheep (Ovis aries). J Vet Pharmacol Ther, 2009, 32, 606-612 (doi: 10.1111/j.1365-2885.2009.01082.x).

25. Kubicek V, Soukupova M, Nobilis M, Krizova V, Szotakova B, Skalova L: LC with fluorimetric detection for sensitive analysis of reduced flubendazole in biological samples. Chromatographia, 2008, 68, 865-867.

26. Lamka J, Nevole Z, Duchacek L, Velik J, Zavrel S: The comparison of mebendazole and flubendazole anthelmintic efficacy in experimental treatment of mouflon (Ovis musimon) muelleriosis. Vet Med-Czech, 2000, 45, 45-48.

27. Lamka J, Vondrejc M, Klecakova J: Efficacy of flubendazole against Muellerius capillaris in mouflon. Vet Med-Czech, 1996, 41, 189-190.

28. Lanusse C, Gascon L, Prichard R: Comparative plasma disposition kinetics of albendazole, fenbendazole, oxfendazole and their metabolites in adult sheep. J Vet Pharmacol Ther, 1995, 18, 196-203.

29. Lanusse C, Prichard R: Clinical pharmacokinetics and metabolism of benzimidazole anthelmintics in ruminants. Drug Metab Rev, 1993, 25, 235-279.

30. Maser E, Oppermann UCT: The $11 \beta$-hydroxysteroid dehydrogenase system, a determinant of glucocorticoid and mineralocorticoid action - Role of type-1 11 $\beta$-hydroxysteroid dehydrogenase in detoxification processes. Eur J Biochem, 1997, 249, 365-369.

31. Maté L, Virkel G, Lifschitz A, Ballent M, Lanusse C: Hepatic and extra-hepatic metabolic pathways involved in flubendazole biotransformation in sheep. Biochem Pharmacol, 2008, 76, 773-783.

32. Mizuma T, Machida M, Hayashi M, Awazu S: Correlation of drug conjugative metabolism rates between in vivo and in vitro: glucuronidation and sulfation of p-nitrophenol as a model compound in rat. J Pharmacobiodyn, 1982, 5, 811-817.

33. Moreno L, Alvarez L, Mottier L, Virkel G, Bruni SS, Lanusse CJ. Integrated pharmacological assessment of flubendazole potential for use in sheep: disposition kinetics, liver metabolism and parasite diffusion ability. J Vet Pharmacol Ther, 2004, 27, 299-308.

34. Mottier L, Alvarez L, Pis M, Lanusse C: Transtegumental diffusion of benzimidazole anthelmintics into $\mathrm{Mo}$ niezia benedeni: correlation with their octanol-water partition coefficients. Exp Parasitol, 2003, 103, 1-7.

35. Nobilis M, Vybiralova Z, Krizová V, Kubicek V, Soukupova M, Lamka J, Szotakova B, Skalova L: Sensitive chiral high-performance liquid chromatographic determination of anthelmintic flubendazole and its phase I me- tabolites in blood plasma using UV photodiode-array and fluorescence detection. Application to pharmacokinetic studies in sheep. J Chromatogr B, 2008, 876, 89-96.

36. Ohara H, Miyabe Y, Deyashiki Y, Matsuura K, Hara A: Reduction of drug ketones by dihydrodiol dehydrogenases, carbonyl reductase and aldehyde reductase of human liver. Biochem Pharmacol, 1995, 50, 221-227.

37. Palackal NT, Burczynski ME, Harvey RG, Penning TM: The ubiquitous aldehyde reductase (AKR1A1) oxidizes proximate carcinogen trans-dihydrodiols to $o$-quinones: Potential role in polycyclic aromatic hydrocarbon activation. Biochemistry, 2001, 40, 10900-10910.

38. Palackal NT, Lee SH, Harvey RG, Blair IA, Penning TM: Activation of polycyclic aromatic hydrocarbon trans-dihydrodiol proximate carcinogens by human aldo-keto reductase (AKR1C) enzymes and their functional overexpression in human lung carcinoma (A549) cells. J Biol Chem, 2002, 277, 24799-24808.

39. Peter R, Bocker R, Beaune PH, Iwasaki M, Guengerich FP, Yang CS: Hydroxylation of chlorzoxazone as a specific probe for human liver cytochrome P-450IIE1. Chem Res Toxicol, 1990, 3, 566-573.

40. Price RJ, Surry D, Renvick AB, Meneses-Lorente G, Lake BG, Evans DC: CYP isoform induction screening in 96-well plates: use of benzyloxytrifluoromethylcoumarin as a substrate for studies with rat hepatocytes. Xenobiotica, 2000, 30, 781-795.

41. Russell GJ, Gill JH, Lacey E: Binding of $\left[{ }^{3} \mathrm{H}\right]$ benzimidazole carbamates to mammalian brain tubulin and the mechanism of selective toxicity of the benzimidazole anthelmintics. Biochem Pharmacol, 1992, 43, 1095-1100.

42. Savlik M, Fimanova K, Szotakova B, Lamka J, Skalova L: Modulation of porcine biotransformation enzymes by anthelmintic therapy with fenbendazole and flubendazole. Res Vet Sci, 2006, 80, 267-274.

43. Savlik M, Polackova L, Szotakova B, Lamka J, Velik J, Skalova L: Activities of biotransformation enzymes in pheasant (Phasianus colchicus) and their modulation by in vivo administration of mebendazole and flubendazole. Res Vet Sci, 2007, 83, 20-26.

44. Skalova L, Szotakova B, Machala M, Neca J, Soucek P, Havlasova J, Wsol V et al.: Effect of ivermectin on activities of cytochromes P450 isoenzymes in mouflon (Ovis musimon) and fallow deer (Dama dama). ChemBiol Interact, 2001, 137, 155-167.

45. Soldan M, Netter KJ, Maser E: Induction of daunorubicin carbonyl reducing enzymes by daunorubicin in sensitive and resistant pancreas carcinoma cells. Biochem Pharmacol, 1996, 51, 117-123.

46. Szotakova B, Baliharova V, Lamka J, Nozinova E, Wsol $\mathrm{V}$, Velik J, Machala M et al.: Comparison of in vitro activities of biotransformation enzymes in pig, cattle, goat and sheep. Res Vet Sci, 2004, 76, 43-51.

47. Szotakova B, Nobilis M, Lamka J, Krizova V, Savlik M, Skalova L: Modulation of porcine (Sus scrofa) and pheasant (Phasianus colchicus) carbonyl reducing enzymes by anthelmintic therapy with flubendazole. Drug Metab Lett, 2008, 2, 29-34.

48. Szotakova B, Skalova L, Wsol V, Kvasnickova E: Reduction of the potential anticancer drug oracin in the rat liver in vitro. J Pharm Pharmacol, 2000, 52, 495-500. 
49. Velik J, Baliharova V, Fink-Gremmels J, Bull S, Lamka J, Skalova L: Benzimidazole drugs and modulation of biotransformation enzymes. Res Vet Sci, 2004, 76, 95-108.

50. Ward SA, Mihaly GW, Tjia JF, Back DJ: The effect of some benzimidazoles on the disposition of antipyrine and tolbutamide from the rat isolated perfused liver. J Pharm Pharmacol, 1985, 37, 62-64.

51. Weaver RJ, Thompson S, Smith G, Dickins M, Elcombe CR, Mayer RT, Burke MD: A comparative study of constitutive and induced alkoxyresorufin O-dealkylation and individual cytochrome-P450 forms in cynomolgus mon- key (Macaca fascicularis), human, mouse, rat and hamster liver-microsomes. Biochem Pharmacol, 1994, 47, 763-773.

52. Wsol V, Szotakova B, Martin HJ, Maser E: Aldo-keto reductases (AKR) from the AKR1C subfamily catalyze the carbonyl reduction of the novel anticancer drug oracin. Toxicology, 2007, 238, 111-118.

Received:

February 19, 2009; in revised form: September 28, 2009 